Syntax Literate : Jurnal Ilmiah Indonesia p-ISSN: 2541-0849 e-ISSN : 2548-1398

Vol. 5 No. 3 Maret 2020

\title{
EVALUASI PAJAK PENGHASILAN ATAS USAHA JASA KONSTRUKSI DALAM MENINGKATKAN KEPATUHAN PERPAJAKAN PADA PT. $X$
}

\section{Ririh Sri Harjanti dan Hetika}

DIII Akuntansi Politeknik Harapan Bersama (HARBER) Tegal

Email: ririh.sriharjanti77@gmail.com dan hetika.maksi@gmail.com

\section{Abstract}

Evaluation of income tax on construction service business in accordance with the taxation regulations is expected to be able to support increasing compliance for taxpayers themselves and for the tax authorities. Taxpayers can avoid miscalculations, deposits, and reporting so as to avoid tax penalties. Until now there is still a lot of confusion about the application of income tax on companies engaged in construction services, as experienced by PT X. The purpose of this study was to determine the proper evaluation of Income Tax on construction services business at PT X in order to achieve tax compliance. The research method used in this study is a descriptive qualitative analysis method that is looking for data about the condition of the field of construction services run by the company, the fulfillment of taxation that has been done in relation to income tax in the field of construction services and drawing conclusions from the results of the study. The results showed that the imposition of income tax on construction service businesses at PT X during 2018 there was only one package of construction service business projects that resulted in the gross circulation of $R p$. 2,747,799,000 not including VAT (Value Added Tax). PT X already has a Business Entity Certificate (SBU). For this income, PT X pays the Final Income Tax Article 4 paragraph (2) with a rate of 3\%, namely Rp.82,433,970. Deposits are made before the 10th of the following month and reporting is done before the 20th of the following month. So it can be concluded that the evaluation of the imposition, deposit, and reporting of income tax on the construction services business of PT X is in accordance with statutory regulations.

Keywords: Income Tax, Construction Services Business

\footnotetext{
Abstrak

Evaluasi pajak penghasilan atas usaha jasa konstruksi yang sesuai dengan peraturan yang perpajakan diharapkan dapat menunjang meningkatkan kepatuhan bagi wajib pajak itu sendiri maupun bagi pihak fiskus. Wajib Pajak bisa terhindar dari kesalahan perhitungan, penyetoran dan pelaporan sehingga terhindar dari sanksi perpajakan. Sampai saat ini masih banyak sekali terjadi kebingungan terhadap penerapan pajak penghasilan pada perusahaan yang bergerak dalam bidang jasa konstruksi, sebagaimana dialami oleh PT X . Tujuan Penelitian ini ialah guna mengetahui evaluasi Pajak Penghasilan dari usaha jasa konstruksi Pada PT X yang tepat dalam rangka mencapai kepatuhan perpajakan. Metode Penelitian yang digunakan pada penelitian ini adalah metode analisis deskriptif Kualitatif
} 
yaitu mencari data tentang kondisi bidang jasa konstruksi yang dijalankan perusahaan, pemenuhan perpajakan yang sudah dilakukan kaitannya dengan pajak penghasilan di bidang jasa konstruksi, dan menarik kesimpulan dari hasil penelitian. Hasil penelitian menunjukkan bahwa pengenaan pajak penghasilan atas usaha jasa konstruksi pada PT X selama tahun 2018 hanya terdapat satu paket proyek usaha jasa konstruksi yang menghasilkan peredaran bruto sebesar Rp. 2.747.799.000 belum termasuk PPN (Pajak Pertambahan Nilai). PT X sudah mempunyai Sertifikat badan Usaha (SBU). Atas penghasilan tersebut maka PT X membayar pajak PPh Final PPh Pasal 4 ayat (2) dengan tarif sebesar $3 \%$ yaitu sebesar Rp 82.433.970. Penyetoran dilakukan sebelum tanggal 10 bulan berikutnya serta pelaporan dilakukan sebelum tanggal 20 bulan selanjutnya. Sehingga dapat disimpulkan bahwa evaluasi dari pengenaan, penyetoran dan pelaporan pajak penghasilan atas usaha jasa konstruksi PT X sudah sesuai dengan peraturan perundang-undangan.

Kata kunci: Pajak Penghasilan, Usaha Jasa Konstruksi

\section{Pendahuluan}

Pajak, dari berbagai pengertian serta fungsi di atas, memang mempunyai andil dalam pembangunan negara (Rusmadi, 2017). Dari tahun ke tahun penerimaan pajak menjadi idola sumber pendapatan Negara Indonesia. Menurut Anggaran Pendapatan serta Belanja Negara (RAPBN) Indonesia tahun 2019 diketahui penerimaan pajak selalu mengalami kenaikan. Diketahui pada tahun 2017 target penerimaan pajak sebesar Rp 1.472,7 Triliun dan tahun 2018 target penerimaan pajak sebesar Rp 1.618,1 Triliun atau naik $9,87 \%$ dari tahun sebelumnya.

Kenaikan target penerimaan pajak juga terjadi pada APBN tahun 2019. Dalam Anggaran Pendapatan dan Belanja Negara (RAPBN) Indonesia tahun 2019 diketahui target Pendapatan Negara secara keseluruhan sebesar Rp 2.165,1 Triliun. Target pendapatan negara secara keseluruhan tersebut mengandalkan akan dipenuhi bersumber penerimaan pajak sebesar Rp 1.786,4 Triliun atau sekitar 82,5\% dari keseluruhan pendapatan negara yang diharapkan. Oleh karena itu sangat wajar apabila pemerintah mengharapkan supaya penerapan peraturan perpajakan dapat ditegakkan dan berjalan sebagaimana mestinya demi keberlangsungan pembangunan Indonesia.

Dalam Undang-undang No 16 tahun 2009 perihal Ketentuan Umum serta Tata Cara Perpajakan Bab 1 pasal 1 no 1 dijelaskan bahwa Pajak merupakan kontribusi wajib terhadap negara yang terutang oleh orang pribadi atau badan yang sifatnya memaksa berdasarkan Undang-undang, dengan tidak memperoleh imbalan secara langsung serta dipergunakan guna keperluan negara bagi sebesar-besarnya kemakmuran rakyat (Republik Indonesia, n.d.). Oleh karena itu berbagai elemen warga Negara sebagai wajib pajak selayaknya untuk mendukung pemerintahan dalam hal ini mematuhi peraturan perundang-undangan perpajakan yang ada di Indonesia.

Memiliki dua macam kepatuhan yakni Kepatuhan Formal serta Kepatuhan Material. Kepatuhan Formal dimana selaras dengan ketentuan dalam undang-undang 
perpajakan. Sedangkan Kepatuhan Material adlah suatu keadaan Dimana wajib pajak secara substansi memenuhi ketentual material perpajakan (Juniarto, 2016)

Sistem pemungutan pajak yang ada di Indonesia menganut sistem Self Assesment System dimana wajib pajak diberi kesempatan dalam menghitung, menyetor serta menyampaikan sendiri atas jumlah pajak yang terutang. Menurut (Kondoy, 2016) menjelaskan bahwa pada penelitian-penelitian sebelumnya menunjukkan penerapan pajak penghasilan di bidang jasa konstruksi ternyata masih mengalami beberapa kendala baik dari peraturannya ataupun dari pihak yang dikenai pajak.

Berkaitan dengan hal di atas maka dapat peneliti sampaikan beberapa kondisi sebagai berikut. Berdasarkan Undang-undang Pajak Penghasilan (PPh) yaitu UU No 36 Tahun 2008 dalam pasal 4 ayat (2) "Penghasilan dibawah ini dapat dikenai Pajak Penghasilan Final" yaitu pada huruf d disebutkan bahwa Penghasilan dari transaksi pengalihan harta berupa tanah dan atau bangunan, usaha jasa konstruksi, usaha real estate, serta persewaan tanah dan/atau bangunan. Dari pasal tersebut dapat dijelaskan bahwa usaha jasa konstruksi sebagai usaha yang penghasilannya dikenai Pajak Penghasilan pasal 4 ayat (2) atau PPh Final. Di sisi lain dalam Undang-undang Pajak Penghasilan yang sama pada Pasal 23 ayat 1 huruf c angka 2 juga menuliskan pajak penghasilan dari "Jasa Konstruksi". Dari bunyi kedua pasal tersebut, menyebabkan banyak wajib pajak ataupun kalangan masyarakat pada umumnya mengalami kebingungan dalam penerapan kedua pasal dalam undang-undang pajak penghasilan tersebut.

Mengingat saat ini jumlah wajib pajak di bidang jasa konstruksi yang tidak sedikit maka perlu dilakukan evaluasi bagaimana penerapan sebenarnya akan kedua bunyi pasal tersebut. Tidak dipungkiri bahwa pajak penghasilan dari jasa konstruksi begitu dominan dalam menyumbang penerimaan pajak di Indonesia.

PT X merupakan perusahaan yang berada dalam bidang usaha jasa konstruksi. Perusahaan ini berlokasi di alamat Jalam Dr. Karyadi RT. 02 RW 04 Dukuhwringin Slawi Kabupaten Tegal. Berdasarkan penelitian sementara diketahui PT X selama ini masih kebingungan dalam menerapkan peraturan perundang-undangan perpajakan kaitannya dengan Pajak Penghasilan dari usaha jasa konstruksi. Mereka masih mengalami kebingungan apakah penghasilan yang diperoleh dipotong Pajak Penghasilan Pasal 4 ayat (2) ataukah Pajak Penghasilan Pasal 23.

Untuk dapat memperoleh kejelasan penerapan peraturan perundang-undangan perpajakan tentang penerapan pajak penghasilan dari usaha jasa konstruksi dan terhindar dari pajak berganda pada PT X serta pada akhirnya dapat mencapai ketertiban dan kepatuhan perpajakan maka perlu dilakukan sebuah evaluasi apakah penerapan pajak penghasilan yang dilaksanakan sudah sesuai atau belum dengan peraturan perundang-undangan tentang pajak penghasilan atas usaha jasa konstruksi.

Berdasarkan permasalahan yang dialami oleh PT X di atas, maka peneliti tertarik untuk melakukan peneltitian dengan judul “ Evaluasi Penerapan Pajak Penghasilan Atas Usaha Jasa Konstruksi Pada PT X . 


\section{Metode Penelitian}

Penelitian ini menggunakan pendekatan deskriptif kuantitatif. Metode deskriptif ialah suatu analisis mengumpulkan, menyusun, mengolah, serta menganalisi data agar dapat memberikan suatu keadaan tertentu sehingga dapat ditarik kesimpulan. (Sugiyono, 2012). Selanjutnya dijelaskan bahwa penelitian deskriptif ialah penelitian yang digunakan guna menyelidiki keadaan kondisi atau hal-hal lain yang telah disebutkan, yang hasilnya dipaparkan berupa laporan penelitian. Jenis data yang digunakan ialah data kuantitatif serta kualitatif dimana menjelaskan tentang bagaimana cara perhitungan, pembayaran dan pelaporan Pajak Penghasilan Atas usaha jasa Konstruksi pada PT X tahun 2018.

\section{Hasil dan Pembahasan}

1. Evaluasi Perhitungan pajak penghasilan atas usaha jasa konstruksi pada PT $\mathbf{X}$

\section{a. Perhitungan Pajak Penghasilan Atas Usaha Jasa Konstruksi Pada PT X.}

Perhitungan pajak penghasilan atas usaha jasa konstruksi pada PT X dihitung berdasarkan Sertifikat Badan Usaha (SBU) yang dimiliki. Berdasarkan sumber data wawancara diperoleh data bahwa atas usaha jasa konstruksi PT X dipotong pajak penghasilan final sebesar 3\% dari penghasilan bruto. Dalam perhitungannya diperoleh data sebagai berikut :

PPh Final $=$ Tarif $x$ Dasar Pengenaan Pajak

$$
\begin{aligned}
& =3 \% \times \text { Penghasilan Bruto } \\
& =3 \% \times \operatorname{Rp~2.747.799.000} \\
& =\operatorname{Rp} 82.433 .970
\end{aligned}
$$

\section{b. Perhitungan Pajak Penghasilan Atas Usaha Jasa Konstruksi Menurut Peraturan Perpajakan}

1) Berdasarkan Undang-undang Pajak Penghasilan Pasal 4 ayat (2)

Berdasarkan Undang-undang Pajak Penghasilan Pasal 4 ayat (2) huruf d disebutkan bahwa : ayat (2) "Penghasilan di bawah ini dapat dikenai pajak bersifat final": d. " penghasilan dari transaksi pengalihan harta berupa tanah dan/atau bangunan, usaha jasa konstruksi, usaha real estate, dan persewaan tanah dan/atau bangunan; dan".

2) Berdasarkan Peraturan Pemerintah (PP) Nomor 51 Tahun 2008 sebagaimana telah diperbaharui dengan PP No 40 Tahun 2009

Dalam Peraturan Pemerintah (PP) Nomor 51 Tahun 2008 disebutkan pada Pasal 2 berbunyi "Atas penghasilan dari usaha Jasa

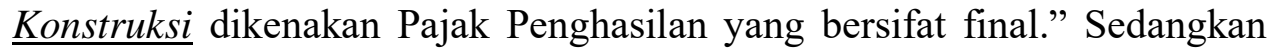
pada pasal 3 ayat (1) berbunyi "Tarif Pajak Penghasilan untuk usaha jasa Konstruksi adalah sebagai berikut :

a) $2 \%$ (dua persen) untuk Pelaksanaan Konstruksi yang dilakukan oleh

Penyedia Jasa yang memiliki kualifikasi usaha kecil. 
b) $4 \%$ (empat persen) untuk untuk Pelaksanaan Konstruksi yang dilakukan oleh Penyedia Jasa yang tidak memiliki kualifikasi usaha

c) $3 \%$ (empat persen) untuk untuk Pelaksanaan Konstruksi yang dilakukan oleh Penyedia Jasa selain Penyedia Jasa sebagaimana dimaksud dalam huruf a dan huruf $b$

d) $4 \%$ (empat persen) untuk untuk Perencanaan Konstruksi atau Pengawasan Konstruksi yang dilakukan oleh Penyedia Jasa yang memiliki kualifikasi usaha; dan

e) 6\% (empat persen) untuk untuk Perencanaan Konstruksi atau Pengawasan Konstruksi yang dilakukan oleh Penyedia Jasa yang tidak memiliki kualifikasi usaha.

Berdasarkan peraturan perpajakan di atas apabila suatu perusahaan mempunyai SBU (Sertifikat Badan Usaha) diartikan bahwa perusahaan tersebut merupakan usaha jasa konstruksi sehingga perusahaan tersebut PT $\mathrm{X}$ dipotong PPh Final yaitu PPh Pasal 4 ayat (2). Selanjutnya berdasarkan Peraturan Presiden No 16 Tahun 2018 pasal 65 ayat (4) disebutkan bahwa Nilai paket pengadaan barang/Pekerjaan Konstruksi/Jasa Lainnya paling banyak Rp 2.500.000.000,00 (dua milyar lima ratus juta rupiah) dicadangkan dan diperuntukkannya bagi usaha kecil. Sehingga PT X yang mempunyai nilai paket pengadaan sebesar $\mathrm{Rp}$ 2.747.799.000 maka termasuk usaha jasa konstruksi kualifikasi usaha menengah atau atas sehingga tarif pajak penghasilan atas usaha Jasa Konstruksinya adalah sebesar 3\% dari penghasilan Bruto.

\section{Evaluasi Pembayaran pajak penghasilan atas usaha jasa konstruksi pada PT $\mathbf{X}$}

Berdasarkan hasil wawancara diperoleh data bahwa pembayaran $\mathrm{PPh}$ Final atas usaha Jasa Konstruksi PT X tidak mengalami keterlambatan artinya selalu tepat waktu. Hal ini dikarenakan pada saat menerima penghasilan, PT X langsung dipotong PPh Final yaitu PPh Pasal 4 ayat (2) oleh pihak pengguna jasa konstruksi dalam hal ini dipotong oleh Dinas Perkimtaru (Perumahan Rakyat, Kawasan Permukiman, Tata Ruang dan Pertanahan) Kabupaten Tegal sebelum tanggal 10 pada bulan berikutnya. Hal ini sesuai dengan Undang-undang No 16 Tahun 2009 tentang KUP (Ketentuan Umum dan Tata Cara Perpajakan).

\section{Evaluasi Pelaporan pajak penghasilan atas usaha jasa konstruksi pada PT X}

Menurut hasil wawancara dengan narasumber, mekanisme pelaporan atau penyampaian SPT (Surat Pemberitahuan) PPh Final atas usaha Jasa Konstruksi Pada PT X tidak mengalami keterlambatan yaitu sebelum tanggal 20 bulan berikutnya. Dalam hal ini perusahaan tidak mau menunjukkan SPT yang disampaikan, sehingga tidak dapat diketahui dengan pasti tanggal persis pelaporan atau penyampaiam SPT PPh Final Atas Usaha Konstruksi pada PT X. Hal ini sesuai 
dengan Undang-undang No 16 Tahun 2009 tentang KUP (Ketentuan Umum dan Tata Cara Perpajakan).

\section{Kesimpulan}

Evaluasi Perhitungan Pajak Penghasilan Atas Usaha Jasa Konstruksi Pada PT X sudah sesuai dengan peraturan perundang-undangan Perpajakan yang berlaku, dimana perhitungan yang dilakukan sesuai dengan PPh pasal 4 ayat 2 dan bukan PPh pasal 23 . PT X merupakan usaha jasa konstruksi dan bukan jasa konstruksi. Evaluasi pembayaran Pajak Penghasilan Atas Usaha Jasa Konstruksi Pada PT X juga sudah sesuai dengan peraturan perundang-undangan Perpajakan yang berlaku karena dibayar sebelum tanggal 10 bulan berikutnya. Hasil evaluasi dari pelaporan Pajak Penghasilan Atas Usaha Jasa Konstruksi Pada PT X sudah sesuai dengan peraturan perundangundangan Perpajakan yang berlaku, karena PT X membayar pajak penghasilan atas usaha Jasa konstruksi sebelum tanggal 20 pada bulan berikutnya. Hal ini dapat dikatakan tidak mengalami keterlambatan sebagaimana Undang-undang No 16 Tahun 2009 pada pasal 3 tentang KUP (Ketentuan Umum dan Tata Cara Perpajakan). Sehingga dapat dikatakan bahwa pelaksanaan perpajakan yang sudah sesuai dengan peraturan perpajakan menunjukkan tingkat kepatuhan perpajakan pada PT X. 
Ririh Sri Harjanti dan Hetika

\section{BIBLIOGRAFI}

Indonesia, R. (n.d.). Undang-Undang Republik Indonesia Nomor 16 Tahun 2009 Tentang Ketentuan Umum dan Tata Cara Perpajakan.

Juniarto, E. A. (2016). Kepatuhan Pemenuhan Kewajiban Pajak Penghasilan Atas Usaha Jasa Konstruksi Di Pt. Prambanan Dwipaka Di Surabaya. Equity, 2(3).

Kondoy, V. C. I. (2016). Analisis penerapan pajak penghasilan jasa konstruksi pada CV. Cakrawala. Jurnal Berkala Ilmiah Efisiensi, 16(4).

Rusmadi, R. (2017). Pengaruh Tax Amnesty dan Sanksi Pajak Terhadap Kepatuhan Wajib Pajak. Syntax Literate; Jurnal Ilmiah Indonesia, 2(3), 124-133.

Sugiyono. (2012). Metode Penelitian Administrasi dilengkapi $R \& D$ (Cetakan Ke). Alfabeta. 